\title{
Determination of Alkyl Esters Content by Gas Chromatography: Validation of Method Based on Short Column and Response Factor
}

\author{
Filipe L. Silva, ${ }^{a}$ Lucas N. Melo, ${ }^{a}$ Carlos R. Wolf, ${ }^{b, c}$ Simoni M. P. Meneghettia and \\ Janaína H. Bortoluzzi*,a \\ ${ }^{a}$ Grupo de Catálise e Reatividade Química, Instituto de Química e Biotecnologia, \\ Universidade Federal de Alagoas, Avenida Lourival de Melo Mota, s/ $n$, \\ Cidade Universitária, 57072-970 Maceió-AL, Brazil \\ ${ }^{b}$ Faculdade de Química, Universidade Luterana do Brasil, Avenida Farroupilha, 8001, \\ 92425-900 Canoas-RS, Brazil
}

'TANAC S.A., Rua Torbjorn Weibull, 199, 95780-000 Montenegro-RS, Brazil

\begin{abstract}
In this study an analytical method, based on gas chromatography with flame ionization detection, using a short column and response factor (GCSCRF), was validated for the quantification of fatty acid alkyl esters (methylic or ethylic). During the validation process, the proposed method was employed to analyze twenty samples of fatty acid methyl esters and fatty acid ethyl esters. Biodiesel samples were produced from soybean oil and the validated method was found to be selective, being able to separate and identify every ester species present in the samples according to its carbon number. When the method was submitted to some variations in the sample preparation procedure, it remained robust. Limits of detection and quantification were 6.76 and $20.4 \mathrm{mg} \mathrm{mL}^{-1}$, respectively. The suggested method also showed great precision when successive analyses were carried out for different analysts, with standard deviation (SD) 0.6 for repeatibility and relative standard deviation (RSD) percentage $7.3 \%$ for intermediate precision, excellent accuracy when compared to other reference methods (EN 14103 and high-performance liquid chromatography with ultraviolet dection (HPLC-UV)) and recovery studies.
\end{abstract}

Keywords: biodiesel, gas chromatography, chromatografic column, response factor

\section{Introduction}

The growing energy crisis, caused by a high consumption of fossil fuels and environmental degradation, has influenced the development of renewable fuels as alternative energy sources. Biodiesel, produced by the transesterification or esterification of vegetable or animal oils and fats or fatty acids, in the presence of an alcohol such as methanol or ethanol, ${ }^{1-3}$ is one of the most promising alternative fuels. Besides being renewable, nontoxic and biodegradable, biodiesel can be added to petrodiesel due to its similar physico-chemical properties. ${ }^{4}$

Pure biodiesel is represented by B100 (100\% fatty acid alkyl esters (FAAE)). However, in the case of biodiesel/petrodiesel blends the abbreviation $\mathrm{BX}$ indicates the percentage volume of B100 in these blends. ${ }^{5}$ Nowadays, a B7 mixture (7\% B100 and 93\% diesel oil) is marketed in Brazil. ${ }^{6}$

*e-mail: janaina.bortoluzzi@iqb.ufal.br
Biodiesel is composed of a mixture of fatty acid methyl esters (FAME) or ethyl esters (FAEE). ${ }^{7}$ The quantification of these esters is conducted using several analytical techniques, particularly gas chromatography (GC) and high-performance liquid chromatography (HPLC). ${ }^{8-14} \mathrm{GC}$ with flame ionization detection (FID) shows excellent selectivity in biodiesel analysis and is the main technique used for this purpose. . $^{8,11,15,16}$

In Brazil, the production and use of biodiesel is regulated and supervised by the Brazilian National Petroleum, Natural Gas and Biofuels Regulatory Agency (ANP) through Resolution No. 45/2014, ${ }^{17}$ in which the European Standard EN14103 ${ }^{18}$ is adopted for the determination of methyl esters by the GC technique. In this case, the external calibration method is used, based on a comparison of the analyte peak area with the peak area of some external standards, analyzed at different concentrations. ${ }^{17}$

In the literature, many studies have demonstrated that the GC technique can be applied to determine the content 
of FAME or FAEE in samples of B100 or in mixtures of diesel and biodiesel, ${ }^{19}$ and it is also used to quantify other substances like the alcohol used in the reaction and also secondary products such as glycerol, monoacylglycerides, diacylglycerides and triacylglycerides. ${ }^{1,220-27}$ However, due to the variety of raw material ${ }^{28,29}$ that can be employed for biodiesel production and the importance of its production in several countries, it is strategic to develop fast ${ }^{30}$ and economically attractive methods, through modifications such as applying different column temperatures and lengths and the use of a different internal standard ${ }^{23}$ exhibiting similar characteristics, but not present in biodiesel composition.

For the validation of methods appropriate for biodiesel analysis in Brazil, the National Institute of Metrology, Quality and Technology (INMETRO) ${ }^{32,33}$ and the Brazilian Health Regulatory Agency (ANVISA) ) $^{31,32}$ have established some parameters for the validation procedure, in order to obtain reproducible results for different samples at different laboratories, to ensure that a new method generates reliable information on the samples.

The validation process is carried out by the evaluation of several analytical performance parameters and, for the validation of methodologies based on the separation of compounds, such as GC and HPLC, the main parameters that must be considered are linearity and range of application, selectivity, precision, accuracy, limit of detection (LOD), limit of quantification (LOQ), robustness and sensitivity. ${ }^{31-44}$

In this study, the validation of an analytical method based on GC, using a short column and response factor (GCSCRF), for the determination of the methyl or ethyl esters content of biodiesel derived from soybean oil is described. This methodology, which has been applied to study the activity of new catalytic systems used in the transesterification reaction performed with different raw materials ${ }^{45-49}$ offers advantages such as convenience, low cost, analysis run time reduction and suitability for use in the industrial sector.

\section{Experimental}

Production and characterization of the soybean biodiesel samples and standard

Biodiesel samples were produced through the transesterification of soybean oil with methanol or ethanol, at different oil:alcohol molar ratios (1:1, 1:2, 1:3 and 1:6) using sodium hydroxide as the catalyst $(0.5$ or $1.0 \%(\mathrm{~m} / \mathrm{m}))$.

Reactions were carried out in a $100 \mathrm{~mL}$ glass reactor coupled to a refrigerated condenser, with magnetic stirring and heating $\left(40\right.$ or $\left.60{ }^{\circ} \mathrm{C}\right)$. The reaction times applied were 5, 10, 15 and $30 \mathrm{~min}$. Samples were then placed in decanting funnels for the separation of the main products: biodiesel and glycerol.

Standard samples of biodiesel (B100) were obtained using the oil:alcohol ratio of $1: 6,1 \%$ of the catalyst $(\mathrm{m} / \mathrm{m})$, a reaction time of $60 \mathrm{~min}$ and temperatures of 60 and $70^{\circ} \mathrm{C}$ for reactions with methanol or ethanol, respectively. The FAAE formation was monitored by proton nuclear magnetic resonance $\left({ }^{1} \mathrm{H} N M R\right) .{ }^{50}$ The NMR spectra were recorded on a Bruker DRX spectrometer-400 (Billerica, USA).

\section{GCSCRF method}

The quantification of alkyl esters obtained from soybean oil was performed by gas chromatography (GC) on a Shimadzu GC-2010 instrument (Kyoto, Japan) with flame ionization detector (FID) at $250{ }^{\circ} \mathrm{C}$, using a split/splitless capillary injection system at $240{ }^{\circ} \mathrm{C}$, split ratio of 80:1, nonpolar VF-1ms (Factor Four, Agilent, USA) capillary column $(2.2 \mathrm{~m} \times 0.25 \mu \mathrm{m} \times 0.25 \mu \mathrm{m})$, hydrogen gas of high purity (99.95\% Linde, Jaboatão dos Guararapes, Brazil) as the carrier gas and $1 \mu \mathrm{L}$ injection volume. The temperature program was: initial temperature $50{ }^{\circ} \mathrm{C}(1 \mathrm{~min})$; heating from 50 to $180{ }^{\circ} \mathrm{C}$ at a rate of $15{ }^{\circ} \mathrm{C} \mathrm{min}-1$; from 180 to $230{ }^{\circ} \mathrm{C}$ at a rate of $7{ }^{\circ} \mathrm{C} \mathrm{min}-1$; and from 230 to $340{ }^{\circ} \mathrm{C}$ at a rate of $30^{\circ} \mathrm{C} \mathrm{min}^{-1}$. The total analysis run time was approximately $21 \mathrm{~min}^{46-49}$

In the sample preparation procedure $0.15 \mathrm{~g}$ of biodiesel was placed in a $1 \mathrm{~mL}$ volumetric flask, $0.08 \mathrm{~g}$ of glyceryl trioctanoate ester internal standard (tricaprylin) was then added and the flask volume was completed with hexane. Such internal standard was adopted for the reason that it is an eight-carbon triacylglyceride (TAG), hence it is not present in the feedstock used for producing biodiesel samples in this study. Furthermore, due the fact that tricaprylin is a TAG, and not a methyl ester as used in most methods, it becomes a suitable internal standard, exhibiting higher retention time avoiding superposition with other expected signals. As a result, biodiesel samples obtained using different alcohol besides methanol could be evaluated without any alteration in results. The yield of alkyl esters $(\% \mathrm{R})$ was calculated using equation 1 :

$\% \mathrm{R}=\frac{\mathrm{m}_{\mathrm{PI}} \times \mathrm{A}_{\mathrm{S}} \times \mathrm{F}}{\mathrm{A}_{\mathrm{PI}} \times \mathrm{m}_{\mathrm{S}}} \times 100$

where $\mathrm{F}$ is the response factor, $\mathrm{m}_{\mathrm{PI}}$ is the internal standard mass $(\mathrm{g}) ; \mathrm{A}_{\mathrm{S}}$ is the sum of peak areas for the esters (between 8.8 and $10.5 \mathrm{~min}$ ); $\mathrm{A}_{\mathrm{PI}}$ is the internal standard peak area (between 15.8 and $16.5 \mathrm{~min}$ ) and $\mathrm{m}_{\mathrm{S}}$ is the weight of the sample. 
The response factor (F) was determined every day using a standard of methylic or ethylic biodiesel and used as a correction factor to estimate the esters content in the other samples of biodiesel. This factor was calculated using equation 2 :

$\mathrm{F}=\frac{\mathrm{m}_{\mathrm{S}} \times \mathrm{A}_{\mathrm{PI}}}{\mathrm{A}_{\mathrm{S}} \times \mathrm{m}_{\mathrm{PI}}}$

\section{Validation of the GCSCRF method}

The method was validated considering parameters given by INMETRO and in the literature. 18,32,33,52,54,55

The selectivity was evaluated by analyzing samples of soybean oil used in the production of the biodiesel samples, a mixture of soybean oil with B100 $(50: 50 \mathrm{~m} / \mathrm{m})$, a tricaprylin sample, and the hexane solvent. Chromatograms were compared to check the ability of the method to separate, identify, and quantify all of the analytes in the presence of interferents.

Linearity was evaluated by constructing an analytic curve with seven different concentrations of FAME in hexane: $0.0012,0.0057,0.0323,0.0524,0.0844,0.1513$ and $0.1746 \mathrm{~g} \mathrm{~mL}^{-1}$. Every experimental point was analyzed in triplicate. The analytic curve was obtained from the ratio between the peak areas of FAME and the internal standard versus the FAME concentration $\left(\mathrm{g} \mathrm{mL}^{-1}\right)$. The linear correlation coefficient (r) was used to evaluate the linearity of the method and curve quality. The same analytic curve was obtained with the FAME concentrations on a logarithmic scale in order to establish the working range.

The LOD and LOQ were determined for the method based on the parameters of the calibration curve and calculated according to equations 3 and 4 , in which s is the estimate of the standard deviation of the response, from the linear regression equation; and $\mathrm{S}$ is the slope of the plotted analytical curve..$^{32,33}$

$$
\begin{aligned}
& \mathrm{LOD}=3.3 \frac{\mathrm{s}}{\mathrm{S}} \\
& \mathrm{LOQ}=10 \frac{\mathrm{s}}{\mathrm{S}}
\end{aligned}
$$

The sensitivity was determined by evaluating the slope of the calibration curve.

The precision was determined by a single analyst on the same instrument and same day. The repeatability method was done as follows: a FAME sample was prepared and analyzed 10 times sequentially and expressed as the standard deviation (SD), considered as the range of error of the proposed methodology. The intermediate precision was determined by another analyst who carried out the analysis on a different day and expressed as the relative standard deviation (RSD).

The robustness was determined to verify stability of the GC method with variations in the sample preparation conditions: changing the solvent and adding sodium chloride $(\mathrm{NaCl})$.

To determine the accuracy, two procedures were applied: (i) method comparison: the proposed GCSCRF method was compared with two reference methods for the quantification of FAME and FAEE (reference method A: EN 14103-GC, ${ }^{17,18}$ and reference method B: HPLC-UV); 52 (ii) recovery tests: methyl biodiesel was fortified with a standard soybean biodiesel at three concentration levels, and each sample was analyzed in triplicate.

\section{Results and Discussion}

\section{Selectivity}

The GCSCRF method showed good selectivity and it was possible to separate, identify and quantify all of the species present in the biodiesel sample (Figure 1). It is important to note that in this method esters are separated out based on the number of carbon atoms. Nevertheless, the method is selective in the quantification of the total FAME or FAEE in the presence of the other components in the sample, given that both methyl and ethyl esters (time of retention $\left(\mathrm{t}_{\mathrm{R}}\right)=8.8-10.5 \mathrm{~min}$ ) are not overlapped by the adopted internal stardard, tricaprylin (eight-carbon triacylglyceride) $\left(\mathrm{t}_{\mathrm{R}}=15.8-16.5 \mathrm{~min}\right)$, nor by soybean triacylglycerides $\left(t_{R}=17.0-17.5 \mathrm{~min}\right)$.

\section{Linearity, working range, LOD and LOQ}

Figure 2 shows the analytical curve for the linearity study. It was observed that the method demonstrated excellent linearity and its response is proportional to the FAME concentrations. The linear correlation coefficient was $r=0.99966$.

When the FAME concentrations were expressed on a logarithmic scale, five experimental points remained in the linear range (Figure 3). Thus, in this case, only these five experimental points were considered, since at least five standard solutions (data points) with different concentrations are required to express the linearity of a methodology.55

Considering the parameters of the analytical curve (standard deviation response, $\mathrm{s}=0.0280$; slope $\mathrm{S}=13.7148$ ), the GCSCRF method had an LOD of $6.7 \mathrm{mg} \mathrm{mL}^{-1}$ and 


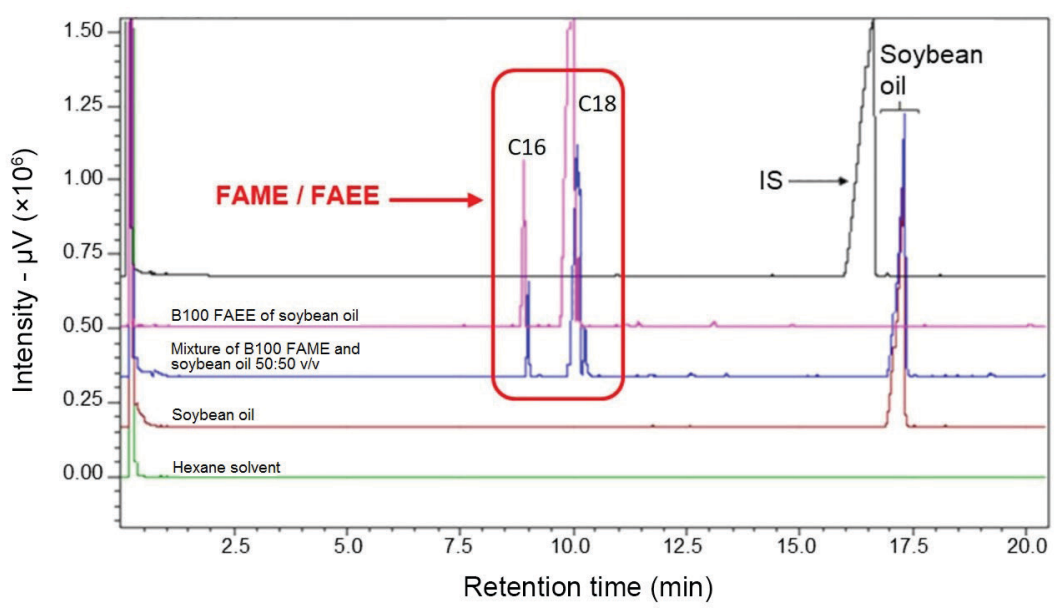

Figure 1. Study on the selectivity through comparison of chromatograms. IS: internal standard (black line); B100 FAEE of soybean oil (pink line); mixture of B100 FAME and soybean oil 50:50 v/v (blue line); soybean oil (red line); and hexane solvent (green line).

LOQ of $20.4 \mathrm{mg} \mathrm{mL}^{-1}$. The LOD establishes the working range $\left(20-170 \mathrm{mg} \mathrm{mL}^{-1}\right)$ of the method.

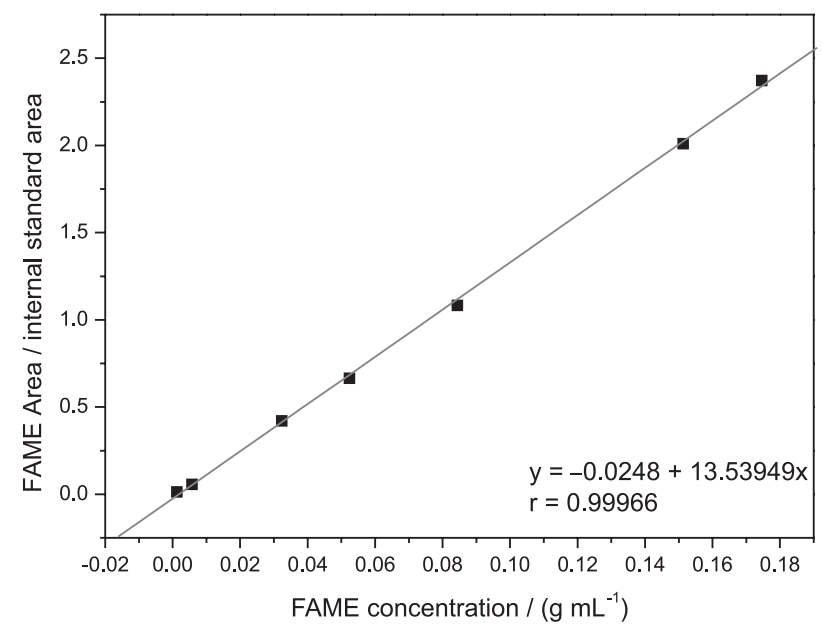

Figure 2. Analytical curve for the analysis of B100 FAME (from soybean oil) at seven different concentrations by the GCSCRF method.

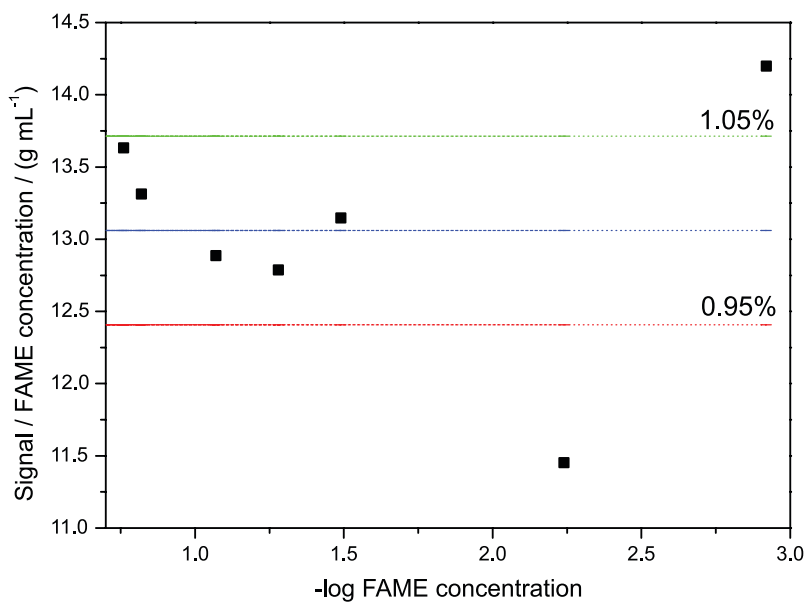

Figure 3. Linearity curve in the range of 95 to $105 \%$ probability: signal/ concentration versus logarithmic scale concentration.
Figure 3 shows the points on the analytical curve that remained in the linear range $(95-100 \%)$. The signals obtained with the method were divided by their respective concentrations, providing the corresponding responses (y-axis), and the logarithmic scale concentrations were expressed on the $\mathrm{x}$-axis. The horizontal line for the median was obtained within the linear range and another two lines were drawn parallel to the median (95 and 105\% of the linear tracking line). In Figure 3, it was observed that the method proved to be linear for five experimental points $\left(0.0323 ; 0.0524 ; 0.0844 ; 0.1513\right.$ and $\left.0.1746 \mathrm{~g} \mathrm{~mL}^{-1}\right)$ of the analytical curve. ${ }^{33}$

It is important to highlight that response factor values with different concentrations of soybean methyl biodiesel standard were obtained, and the internal standard concentration was kept fixed (Figure 3). Based on the values of the response factors obtained, it was possible to calculate the error, which was \pm 0.026 , and therefore, the typical response factor values obtained with the methylic biodiesel standard (0.828) and the ethylic biodiesel standard (0.875) are considered statistically equivalent. Despite the presence of one extra carbon in the soybean ethylic biodiesel chain, this was not significant to decrease the response factor, which was expected by the use of FID detection.

\section{Precision}

In the study of repeatability, the standard deviation was 0.6 . In the study of intermediate precision, the relative standard deviation $(\mathrm{RSD}=7.3$ ) is within the acceptable limits for methods to quantify compounds in macro amounts (RSD 1-2\%) and methods to determine trace concentrations or impurities (RSD 20\%). ${ }^{33}$ The SD $( \pm 0.6)$ was considered as the range or error of the proposed methodology. 


\section{Accuracy}

Tables 1 and 2 show results obtained by analysis of the 20 samples of methylic and 20 samples of ethylic biodiesel, respectively, in order to evaluate the accuracy of the GCSCRF methodology when compared to the other two found in the literature. ${ }^{18,52}$

Table 1. Results obtained by analysis of 20 methylic biodiesel samples using all three methodologies during accuracy evaluation

\begin{tabular}{|c|c|c|c|}
\hline \multirow[b]{2}{*}{ Sample } & \multicolumn{3}{|c|}{ Yield of FAME / \% } \\
\hline & $\begin{array}{c}\text { GCSCRF } \\
(\mathrm{SD}=0.6)\end{array}$ & $\begin{array}{c}\mathrm{EN} 14103^{18} \mathrm{GC} \\
(\mathrm{SD}=1)\end{array}$ & $\begin{array}{c}\text { HPLC-UV } \\
(\mathrm{SD}=1)\end{array}$ \\
\hline 1 & 6.2 & 6 & 8 \\
\hline 2 & 11.0 & 11 & 13 \\
\hline 3 & 14.2 & 13 & 17 \\
\hline 4 & 26.4 & 26 & 28 \\
\hline 5 & 57.0 & 54 & 57 \\
\hline 6 & 70.7 & 64 & 69 \\
\hline 7 & 80.2 & 70 & 82 \\
\hline 8 & 25.0 & 21 & 26 \\
\hline 9 & 27.0 & 25 & 29 \\
\hline 10 & 68.2 & 69 & 68 \\
\hline 11 & 15.6 & 14 & 17 \\
\hline 12 & 14.5 & 13 & 16 \\
\hline 13 & 58.6 & 57 & 55 \\
\hline 14 & 85.7 & 87 & 87 \\
\hline 15 & 72.4 & 72 & 70 \\
\hline 16 & 70.0 & 70 & 70 \\
\hline 17 & 33.0 & 28 & 33 \\
\hline 18 & 78.1 & 86 & 81 \\
\hline 19 & 48.1 & 46 & 46 \\
\hline 20 & 60.1 & 63 & 59 \\
\hline
\end{tabular}

FAME: fatty acid methyl ester; GCSCRF: gas chromatography using a short column and response factor; SD: standard deviation; HPLC-UV: high-performance liquid chromatography with ultraviolet detection.

Considering the SD values, the results presented at Tables 1 and 2 show that all analysed samples display similar values, in terms of yield of FAME (\%) or FAEE (\%), respectively, compared at least to one of the methodologies from literature. ${ }^{18,52}$

Fisher's $F$-test was applied to results of variancy $\left(\mathrm{SD}^{2}\right)$, in order to evaluate their significance.

The calculated value, $F_{\text {experimental }}=2.778$, (obtained comparing the methodologies, since the determined variances of the two methodologies are the same) was smaller than the theoretical value $\left(F_{\text {theoretical }}=2.978\right)$ with
Table 2. Results obtained by analysis of 20 ethylic biodiesel samples using all three methodologies during accuracy evaluation

\begin{tabular}{|c|c|c|c|}
\hline \multirow[b]{2}{*}{ Sample } & \multicolumn{3}{|c|}{ Yield of FAEE / \% } \\
\hline & $\begin{array}{l}\text { GCSCRF } \\
(\mathrm{SD}=0.6)\end{array}$ & $\begin{array}{c}\text { EN } 14103^{18} \mathrm{GC} \\
(\mathrm{SD}=1)\end{array}$ & $\begin{array}{c}\text { HPLC-UV } \\
(\mathrm{SD}=1)\end{array}$ \\
\hline 21 & 5.8 & 5 & 7 \\
\hline 22 & 10.4 & 8 & 11 \\
\hline 23 & 16.1 & 13 & 17 \\
\hline 24 & 16.5 & 14 & 18 \\
\hline 25 & 36.4 & 36 & 37 \\
\hline 26 & 29.3 & 25 & 29 \\
\hline 27 & 48.3 & 41 & 47 \\
\hline 28 & 61.5 & 55 & 62 \\
\hline 29 & 48.1 & 46 & 49 \\
\hline 30 & 25.0 & 21 & 27 \\
\hline 31 & 67.1 & 68 & 63 \\
\hline 32 & 95.2 & 94 & 90 \\
\hline 33 & 44.2 & 40 & 42 \\
\hline 34 & 65.0 & 59 & 58 \\
\hline 35 & 79.5 & 70 & 77 \\
\hline 36 & 64.6 & 60 & 58 \\
\hline 37 & 84.4 & 71 & 85 \\
\hline 38 & 47.9 & 36 & 47 \\
\hline 39 & 39.9 & 36 & 39 \\
\hline 40 & 66.0 & 57 & 65 \\
\hline
\end{tabular}

FAEE: fatty acid ethyl ester; GCSCRF: gas chromatography using a short column and response factor; SD: standard deviation; HPLC-UV: highperformance liquid chromatography with ultraviolet detection.

$5 \%$ of probability. Since $F_{\text {experimental }} \leq F_{\text {theoretical }}$, the GCSCRF results can be considered accurate.

Figures $4 \mathrm{a}$ and $4 \mathrm{~b}$ show, graphically, the degrees of concordance between results displayed on Tables 1 and 2, comparing GCSCRF, EN $14103^{18}$ and HPLC-UV ${ }^{52}$ methods, for methyl and ethyl soybean biodiesel, respectively.

Based on the results reported in Figures $4 a$ and $4 b$, the determination coefficient $\left(\mathrm{r}^{2}\right)$ was obtained for all comparisons, as follows: for FAME analysis $(i) \mathrm{r}^{2}=0.9932$ (GCSCRF versus EN 14103) and (ii) $\mathrm{r}^{2}=0.9924$ (GCSCRF versus HPLC-UV); and for the FAEE content (iii) $\mathrm{r}^{2}=0.9810(\mathrm{GCSCRF}$ versus EN14103) and (iv) $\mathrm{r}^{2}=0.9924$ (GCSCRF versus HPLC-UV).

The values of determination coefficient, for methylic or ethylic biodiesel, indicate that $99 \%$ of the GCSCRF results can be justified by HPLC-UV technique, meanwhile only $1 \%$ of the variation can not be explained, being due to experimental errors. The same situation was observed in the case of the coefficient of determination obtained comparing 

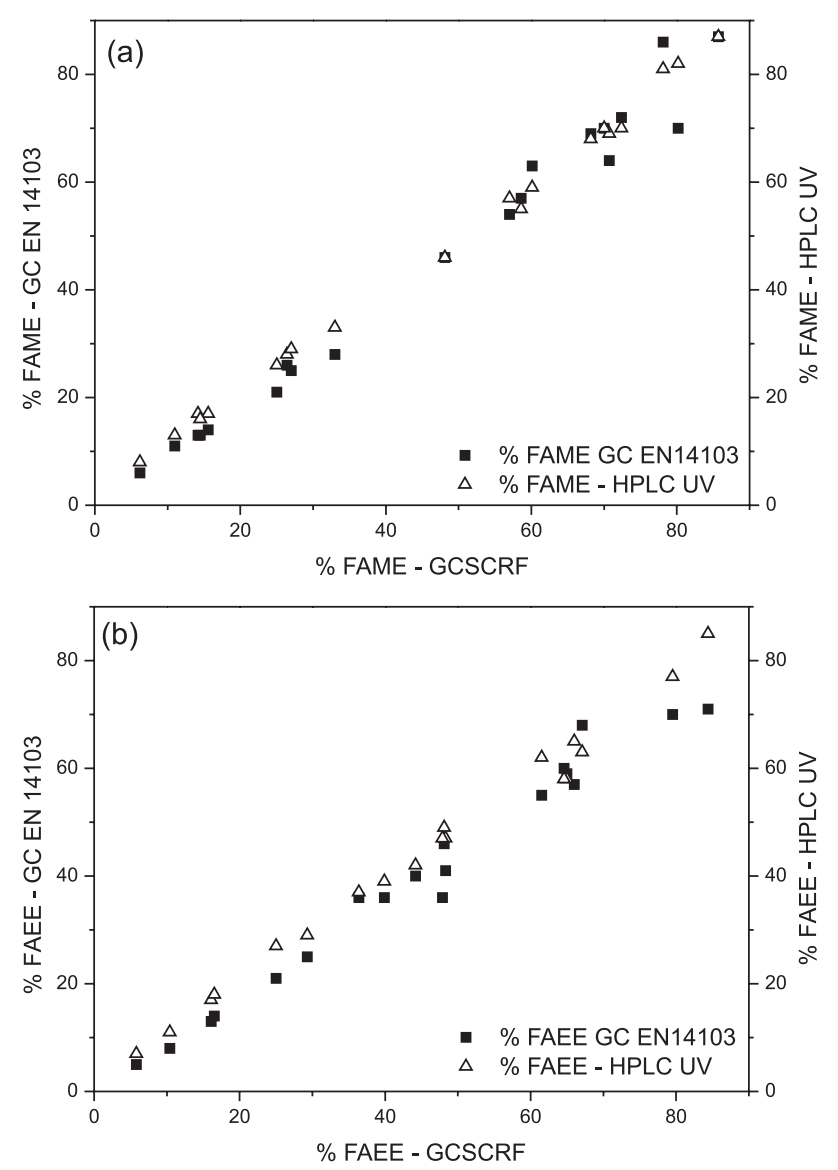

Figure 4. Results for analysis of (a) FAME and (b) FAEE (from soybean oil) samples: GCSCRF method versus the reference methods.

GCSCFR and EN14103 for methylic biodiesel. However, for the ethylic samples $98 \%$ of results can be justified, and $2 \%$ of variation can be related to errors. ${ }^{55}$

\section{Robustness}

Considering the error determined in the accuracy study ( \pm 0.6$)$, the GC method is robust, since it did not show significant variations in the conversion values after modification of the solvent used in the sample preparation and changing the ionic strength of the sample (Table 3).

Table 3. Changes in a FAME sample preparation procedure to evaluate the robustness of the GCSCRF method

\begin{tabular}{lccc}
\hline \multirow{2}{*}{ Solvent } & \multicolumn{2}{c}{ Conversion $\pm 0.6 / \%$} & \multirow{2}{*}{ Average / \% } \\
\cline { 2 - 3 } & $1^{\text {st }}$ analysis & $2^{\text {nd }}$ analysis & \\
\hline Hexane & 9.6 & 9.4 & 9.5 \\
2-Propanol/toluene & 10.5 & 10.3 & 10.4 \\
Hexane/NaCl & 10.3 & 10.0 & 10.1 \\
\hline
\end{tabular}

\section{Recovery test}

Table 4 shows the results obtained in the recovery tests for sample 2 (11\% FAME), spiked with three concentrations of the standard FAME B100. In this study, samples were prepared in semi-micro concentrations. The RSD values were between $0.87-2.00 \%$ and the results obtained in the recovery tests were between 89.81 and $99.61 \%$. These results indicate that the GCSCRF method is very accurate, which is consistent with the literature. ${ }^{33}$

Statistical analysis of the recovery study significance was performed using Student's $t$-test. The calculated value $\left(t_{\text {expeimental }}=2.05\right)$ was less than the theoretical value $\left(t_{\text {theoretical }}=4.3\right)$ with $95 \%$ of confidence and $(n-1)$ degrees of freedom. Since $t_{\text {experimental }} \leq t_{\text {theoretical }}$, the GCSCRF results can be considered accurate.

\section{Conclusions}

The method was validated and demonstrated to be suitable for the determination of FAME or FAEE in soybean biodiesel. All figures of merit evaluated verified the

Table 4. Recovery tests with spiking of methyl soybean biodiesel sample 2 (11\% FAME), with three levels of FAME B100

\begin{tabular}{|c|c|c|c|c|c|c|c|}
\hline Sample weight / $g$ & B100 added / g & $\mathrm{R}^{\mathrm{a}} / \%$ & Recovery / g & Recovery / \% & $\begin{array}{c}\text { Average } \\
\text { recovery / \% }\end{array}$ & $\mathrm{s}^{\mathrm{b}}$ & $\operatorname{RSD}^{\mathrm{c}} / \%$ \\
\hline & & 32.2 & 0.0329 & 98.62 & & & \\
\hline \multirow[t]{3}{*}{0.1048} & 0.0334 & 31.3 & 0.0317 & 94.90 & 97.10 & 1.95 & 2.00 \\
\hline & & 32.0 & 0.0327 & 97.80 & & & \\
\hline & & 37.5 & 0.0458 & 89.81 & & & \\
\hline \multirow[t]{3}{*}{0.1008} & 0.0510 & 37.6 & 0.0460 & 90.11 & 90.44 & 0.79 & 0.87 \\
\hline & & 38.0 & 0.0465 & 91.30 & & & \\
\hline & & 47.0 & 0.0692 & 98.15 & & & \\
\hline \multirow[t]{2}{*}{0.1004} & 0.0706 & 46.1 & 0.0678 & 95.97 & 97.90 & 1.83 & 1.87 \\
\hline & & 47.6 & 0.0703 & 99.61 & & & \\
\hline
\end{tabular}

${ }^{a}$ Methyl esters yield determined in triplicate; ${ }^{\mathrm{b}}$ standard deviation; 'relative standard deviation. 
reliability of the method, with good precision, accuracy and robustness, for continuous use. In addition, the GCSCRF method, based on internal standardization with a response factor, provided results consistent with those obtained applying two other methods commonly used for this type of analysis.

\section{Acknowledgments}

Financial support from the Brazilian research funding agencies Research and Projects Financing (FINEP), National Council of Technological and Scientific Development (CNPq), Brazilian Federal Agency for the Support and Evaluation of Graduate Education (CAPES), and Alagoas Research Support Foundation (FAPEAL), are gratefully acknowledged. S. M. P. M. thanks CNPq for research fellowships. F. L. S. thanks CAPES for a fellowship and L. N. M. thanks CNPq for a PIBIC fellowship.

\section{References}

1. Faria, R. C. M.; Rezende, M. J. C.; Rezende, C. M.; Pinto, A. C.; Quim. Nova 2010, 30, 1900.

2. Santos, R. C. R.; Vieira, B. V.; Valentini, A.; Microchem. J. 2013, 109, 46.

3. Portela, N. A.; Oliveira, E. C. S.; Neto, A. C.; Rodrigues, R. R. T.; Silva, S. R. C.; Castro, E. V. R.; Filgueiras, P. R.; Fuel 2016, 166, 12.

4. Huang, Z.; Zhang, P.; Sun Y.; Huang, Y.; Pan, Z.; Wang, L.; J. Anal. Appl. Pyrolysis 2015, 113, 288.

5. Ministério de Minas e Energia; Boletim Mensal dos Combustiveis Renováveis, No. 96, 2016. Available at http://www.mme.gov.br/documents/1138769/1732805/ Boletim+DCR+n\%C2\%BA+96+-+fevereiro+de+2016. pdf/9db5f193-af66-4124-80c1-0abc74ed63f7, accessed in December 2017.

6. Guabiroba, R. C. S.; Silva, R. M.; Cesar, A. S.; Silva, M. A. V.; J. Cleaner Prod. 2017, 142, 3928.

7. Hejazi, L.; Ebrahimi, D.; Guilhaus, M.; Hibbert, D. B.; Anal. Chem. 2009, 81, 1450.

8. Chattopadhyay, S.; Das, S.; Sem, R.; Appl. Energy 2011, 88, 5188.

9. Sitko, R.; Zawisza, B.; Kowalewsk, Z.; Kocot, K.; Polowniak, M.; Talanta 2011, 85, 2000.

10. Oliveira, T. J. S.; Montalvão, R.; Daher, L.; Suarez, P. A. Z.; Rubim, J. C.; Talanta 2006, 69, 1278.

11. Sousa, F. P.; Luciano, M. A.; Pasa, V. M. D.; Fuel Process. Technol. 2013, 109, 133.

12. Nagy, K.; Jakab, A.; Fekete, J.; Ve'key, K.; Anal. Chem. 2014, 76, 1935.

13. Filgueiras, P. R.; Alves, J. C. L.; Talanta 2014, 119, 582.
14. Shimamoto, G. G.; Bianchessi, L. F.; Tubino, M.; Talanta 2017, $168,121$.

15. Sobrado, L. S.; Freije-Carrelo, L.; Moldovan M.; Encinar, J. R.; Alonso, J. I. G.; J. Chromatogr. A 2016, 1457, 134.

16. Delmonte, P.; Fardin-Kia, A. R.; Rader, J. I.; Anal. Chem. 2013, $85,1517$.

17. Agência Nacional de Petróleo, Gás Natural e Biocombustíveis (ANP); Resolução ANP No. 45 de 25/08/2014, Dispõe sobre a Especificação do Biodiesel Contida no Regulamento Técnico ANP No. 3 de 2014 e as Obrigações quanto ao Controle da Qualidade a Serem Atendidas pelos Diversos Agentes Econômicos que Comercializam o Produto em Todo o Território Nacional, DOU: Brasília, 2014.

18. EN 14103; Fat and Oil Derivatives. Fatty Acid Methyl Esters (FAME). Determination of Ester and Linolenic Acid Methyl Ester Contents, European Committee for Standardization: Brussels, 2001.

19. Seeley, J. V.; Seeley, S. K.; Anal. Chem. 2013, 85, 557.

20. Tiyapongpattana, W.; Wilairat, P.; Marriott, P. J.; J. Sep. Sci. 2008, 14, 2640.

21. Cortes, H. J.; Winniford, B.; Luong, J.; Pursch, M.; J. Sep. Sci. 2009, 32, 883.

22. Ragonese, C.; Tranchida, P. Q.; J. Chromatogr. A 2009, 1216, 8992.

23. Marques, M. V.; Naciuk, F. F.; Mello, A. A. S.; Seibel, N. M.; Fontoura, L. A. M.; Quim. Nova 2010, 33, 978.

24. Gama, P. E.; Gil, R. A. S. S.; Lachter, E. R.; Quim. Nova 2010 , 33, 1859.

25. Moraes, M. A. S.; Zini, C. A.; Gomes, C. B.; Bortoluzzi, J. H.; Mühlen, C. V.; Caramão, E. B.; Quim. Nova 2011, 34, 1188.

26. Souza, G. K.; Scheufele, F. B.; Pasa, T. L. B.; Arroyo, P. A.; Pereira, N. C.; Anal. Chem. 2008, 80, 8712.

27. Knothe, G.; J. Am. Oil Chem. Soc. 2006, 83, 823.

28. Canesin, E. A.; Oliveira, C. C.; Matsushita, M.; Dias, L. F.; Pedrão, M. R.; Souza, N. E.; J. Biotechnol. 2014, 17, 39.

29. Pardo, V. L.; Fagundes, C. A. M.; Caldas, S. S.; Kurz, C. M.; Clementin, R. M.; D’Oca, M. G. M.; Primel, F. G.; J. Am. Oil Chem. Soc. 2012, 89, 631.

30. Sato, R. T.; Stroppa, P. H. F.; Silva, A. D.; Oliveira, M. A. L.; Quim. Nova 2016, 39, 352.

31. Agência Nacional de Vigilância Sanitária (ANVISA), Resolução No. 899 de 29/5/2003, Guia para Validação de Métodos Analíticos e Bioanalíticos, DOU: Brasília, 2003, seção I.

32. Ribani, R.; Bottoli, C. B. G.; Collins, C. H.; Jardim, I. C. F. S.; Melo, L. F. C.; Quim. Nova 2004, 27, 771.

33. Instituto Nacional de Metrologia, Normalização e Qualidade Industrial (INMETRO); DOQ-CGCRE-008, Orientações sobre Validação de Métodos Analíticos, 2011. Available at http://www.inmetro.gov.br/Sidoq/Arquivos/Cgcre/DOQ/DOQCgcre-8_04.pdf, accessed in December 2017. 
34. Thompson, M.; Ellison, S. L. R.; Wood, R.; Pure Appl. Chem. 2002, 74, 835 .

35. Swartz, M. E.; Krull, I. S.; Pharm. Technol. 1998, 2, 12.

36. Miller, J. N.; Miller, J. C.; Statistics and Chemometrics for Analytical Chemistry, $6^{\text {th }}$ ed.; Pearson: Harlow, UK, 2010.

37. Majoros, L. I.; Lava, R.; Ricci, M.; Binici, B.; Sandor, F.; Held, A.; Emons, H.; Talanta 2013, 116, 251.

38. Meira, M.; Quintella, C. M.; Neto, P. R. C.; Pepe, I. M.; Ribeiro, E. M. O.; Silva, W. L.; Cid, A. L. D.; Guimarães, A. K.; Spectrochim. Acta, Part A 2015, 136, 726.

39. Rozet, E.; Ziemons, E.; Marini, R. D.; Boulanger, B.; Hubert, Ph.; Anal. Chem. 2016, 88, 3264.

40. Levine, K. E.; Young, D. J.; Afton, S. E.; Harrington, J. M.; Essader, A. S.; Weber, F. X.; Fernando, R. A.; Thayer, K.; Hatch, E. E.; Robinson, V. G.; Waidyanatha, S.; Talanta 2015, $140,115$.

41. Mendoza, L. G.; González-Álvarez, J.; Gonzalo, C. F.; AriasAbrodo, P.; Altava, B.; Luis, S. V.; Burguete, M. I.; GutiérrezÁlvarez, M. D.; Talanta 2015, 143, 212.

42. Ferrone, V.; Carlucci, M.; Cotellese, R.; Raimondi, P.; Cichella, A.; Di Marco, L.; Carlucci, G.; Talanta 2017, 164, 64.

43. Garballo-Rubio, A.; Soto-Chinchilla, J.; Moreno, A.; ZafraGómez, A.; Talanta 2017, 165, 267.

44. Green, J. M.; Anal. Chem. 1996, 68, 305.

45. Silva, J. P. V.; Brito, Y. C.; Fragoso D. M. A.; Mendes, P. R.; Barbosa, A. S. L.; Bortoluzzi, J. H.; Meneghetti, M. R.; Meneghetti, S. M. P.; Catal. Commun. 2015, 58, 204.
46. Meneghetti, S. M. P.; Bortoluzzi, J. H.; Silva, F. L.; Freitas, J. A. S.; Salgueiro, B.; Melo, L. N.; Silva, W. W. L.; Nascimento, J. R. In Parâmetros Físico-Químicos para os Processos de Produção de Biodiesel; Meneghetti, S. M. P.; Suarez, P. A. Z., eds.; MCTI/RBTB: Brasília, Brasil, 2015, ch. 2.

47. Barbosa, D. C.; Serra, T. M.; Meneghetti, S. M. P.; Meneghetti, M. R.; Fuel 2010, 89, 3791.

48. Almerindo, G. I.; Probst, L. F. D.; Campos, C. E. M.; Almeida, R. M.; Meneghetti, S. M. P.; Meneghetti, M. R.; Clacens, J. M.; Fajardo, H. V.; J. Power Sources 2011, 196, 8057.

49. Jesus, M. P. M.; Melo, L. N.; Silva, J. P. V.; Crispim, A. C.; Figueiredo, I. M.; Bortoluzzi, J. H.; Meneghetti, S. M. P.; Energy Fuels 2015, 29, 7343.

50. Vieira, H. P.; Neves, A. A.; Queiroz, M. E. L. R.; Quim. Nova 2007, 30, 535.

51. Abreu, A. B. G.; Matta, M. H. R.; Montagner, E.; Quim. Nova 2008, 31, 5 .

52. Carvalho, M. S.; Mendonça, M. A.; Pinho, D. M. M.; Resckc, I. S.; Suarez, P. A. Z.; J. Braz. Chem. Soc. 2012, 23, 763.

53. Araujo, P.; J. Chromatogr. B 2009, 877, 2224.

54. Colton, T.; Freedman, L. S.; Johnson, A. L.; Statistics in Medicine, vol. 1; John Wiley and Sons: New York, 1982.

55. Larson, R.; Farber, B.; Estatística Aplicada, vol. 1; Pearson: São Paulo, 2010.

Submitted: September 6, 2017 Published online: December 14, 2017 